\title{
An Empirical Study on the Overreaction of Shanghai Stock Market
}

\author{
Hu Lin ${ }^{1 *}$, Sha Zi-Jun ${ }^{1}$, Liu Xiu-Yi ${ }^{2}$, Chen Wen-Jun ${ }^{2}$ \\ ${ }^{1}$ University of Toyama, Toyama, Japan \\ ${ }^{2}$ Central South University of Forestry and Technology, Changsha, China \\ Email: "hulin1015@hotmail.com
}

Received November 12 $2^{\text {th }}, 2012$; revised December 12 $2^{\text {th }}, 2012$; accepted December $19^{\text {th }}, 2012$

\begin{abstract}
Based on both Chinese and non-Chinese research results, this study uses the research methods of De Bondt and Thaler, selects the trading data from January 2007 to June 2011 in stock market in Shanghai, and tests whether there has been overreaction in the stock market. The empirical result shows more abnormal return of loser portfolio than that of winner portfolio, which indicates over-reaction of the stock market. Moreover, the term is longer and the reversion degree of return is weaker. The result means that the risk difference between winner and loser portfolios does not adequately explain the over-reaction. The main reason for the overreaction we think is the institutional background and other constraining conditions of the stock market in the Chinese mainland.
\end{abstract}

Keywords: Over-Reaction; Cumulative Abnormal Return; Risk Premium

\section{Introduction}

Overreaction on stock market (OSM henceforth) is a major event caused by dramatic change of stock price; it exceeds the expected theoretical level, and then returns to its normal price by way of reverse correction (Liu Li, 1999). De Bondt and Richard are the forerunners in the study of OSM. According to their research, there was reversion on stock return in the long term because of investors' irrational behavior (De Bondt \& Thaler, 1985). Lehmann (1990) identified the factors that reversed the market in a short time interval, but short-term profitability can hardly be identified with overreaction. Rather, it is probably a result of pressures of price in short-term or lacking of liquidity (Lehmann, 1990).

From the late 1990s, Chinese scholars have studied the OSM in China. Through analyzing the stock market in Shanghai, Zhang Renji 张人瀷, Zhu Pingfang 朱平方, and Wang Huaifang 王怀芳 (1998) identified a falling trend on winner portfolio, but found no rising trend on loser portfolio. In other words, they found no OSM in Shanghai. Likewise, in his study of the Shenzhen stock market, Zhu Shaoxing 朱少醒 (2000) found no OSM in China. Song Xianzhong 宋献中 and Tang Sheng 汤胜 (2006) conducted empirical study on the topic of overreaction and scale effect on the corporations listed in A-share market in Shanghai. They found that the return of winner portfolio higher in formation period is lower than that of loser portfolio in the test period. Moreover, they found both the existence of over-reaction, and the significant role played therein by size of the companies, specifically, they found that the return of small-scale winner portfolio was higher than that of the large-scale loser portfolio. These results indicate that, for the return of the listed corporations, the influence of scale effect is higher than that of over-reaction.

Where OSM is concerned, these studies profoundly disagree. But they seem inclined to accept reversion of price in the long

\footnotetext{
*Corresponding author.
}

term. Regarding this phenomenon, no consensus has been reached among Chinese scholars yet (Song Xianzhong \& Tang Sheng, 2006).

\section{Sample Selection and Test Methods}

This paper extracted randomly 100 stocks from the Shanghai stock market, The timeframe under examination is set between January 2007 and June 2011, and the data examined are the daily closing prices in that period. Considering stock dividends and right offerings, calculated for each stock is the return by the price after excluded right. If a stock was in suspension, it meant that the stock's closing price remained the same. Based on the sequence of the level of cumulative abnormal returns in formation period, the 20 top stocks constituted the winner portfolio, and the loser portfolio was composed of the 20 lowest stocks.

\section{The Sorting Methods in Formation Period}

The formation period in the paper is divided into 3 months, 6 months, 12 months and 24 months and the corresponding test period is divided into 1 month, 3 months, 6 months, and 12 months. Let the reference time be $\mathrm{T}_{0}$, the length of formation period be $T_{1}$, and the length of test period be $T_{2}$, then $\left(T_{0}-T_{1}\right.$, $\left.T_{1}\right)$ is the formation period, and $\left(T_{0}, T_{0}+T_{2}\right)$ is the test period. If reference time were constantly, it could also get more combination of formation period and test period. The formations period and test period of these combinations do not overlap, but the current test period and the next formation period may overlap.

The calculations of combined abnormal returns use marketing adjustment, as it was used by the Bolt, Nazareth and Zeluo. The formula is $\mathrm{ER}_{\mathrm{i}, \mathrm{k}}=\mathrm{R}_{\mathrm{i}, \mathrm{k}}-\mathrm{R}_{\mathrm{m}, \mathrm{k}} ; \mathrm{i}=1, \cdots, \mathrm{n}$.

$R_{i, k}$ is yield of stock I in k month.

$R_{m, k}$ is yield of market in $k$ month.

Cumulative abnormal return of stock I in formation period is 
$\mathrm{CER}_{\mathrm{i}}=\sum_{\mathrm{k}} \mathrm{ER}_{\mathrm{i}, \mathrm{k}}$

\section{The Test Methods in Test Period}

Based on the sequence of the level of cumulative abnormal returns in formation period, the 20 top stocks made the winner portfolio and the 20 lowest stocks made the loser portfolio, then the calculated average abnormal monthly returns of each combination are

$$
\begin{aligned}
& \mathrm{AR}_{\mathrm{w}, \mathrm{k}}=\frac{\sum_{\mathrm{i}} \mathrm{ER}_{\mathrm{i}, \mathrm{k}}^{\mathrm{w}}}{\mathrm{n}_{1}} \\
& \mathrm{AR}_{1, \mathrm{k}}=\frac{\sum_{\mathrm{i}} \mathrm{ER}_{\mathrm{i}, \mathrm{k}}^{1}}{\mathrm{n}_{1}} \\
& \mathrm{CAR}_{\mathrm{w}, \mathrm{k}}=\sum_{\mathrm{k}} \mathrm{AR}_{\mathrm{w}, \mathrm{k}} \\
& \mathrm{CAR}_{1, \mathrm{k}}=\sum_{\mathrm{k}} \mathrm{AR}_{1, \mathrm{k}}
\end{aligned}
$$

$\mathrm{AR}_{\mathrm{w}, \mathrm{k}}$ is the average abnormal monthly returns of winner portfolio, $\mathrm{AR}_{1, \mathrm{k}}$ is the average abnormal monthly returns of loser portfolio, $\mathrm{CAR}_{\mathrm{w}, \mathrm{k}}$ is the average cumulative abnormal monthly returns of winner portfolio, and $\mathrm{CAR}_{1, \mathrm{k}}$ is the average cumulative abnormal monthly returns of loser portfolio.

\section{Significance Test}

When calculating cumulative excess returns of each month's winner portfolio and loser portfolio in the test period, at a certain test level, if $\left(\mathrm{CAR}_{\mathrm{l}, \mathrm{k}}-\mathrm{CAR}_{\mathrm{w}, \mathrm{k}}\right)$ is significantly above zero, then there is over-reaction; If $\left(\mathrm{CAR}_{\mathrm{l}, \mathrm{k}}-\mathrm{CAR}_{\mathrm{w}, \mathrm{k}}\right)$ is significantly below zero, then there is inadequate response.

In the test period, once the difference $\left(\mathrm{CAR}_{1, \mathrm{k}}-\mathrm{CAR}_{\mathrm{w}, \mathrm{k}}\right)$ in cumulative abnormal monthly returns between the loser and winner portfolios significantly deviates from zero, we could get the statistic $\mathrm{T}$ of $\mathrm{t}$, and test significance of statistics at the $10 \%$ level. Statistic $\mathrm{T}$ is as follows:

$$
\begin{aligned}
& \mathrm{T}_{\mathrm{t}}= \frac{\left(\mathrm{CAR}_{1, \mathrm{k}}-\mathrm{CAR}_{\mathrm{w}, \mathrm{k}}\right)}{\sqrt{\left(\mathrm{n}_{1}-1\right) \mathrm{S}_{\mathrm{w}, \mathrm{k}}^{2}}+\left(\mathrm{n}_{2}-1\right) \mathrm{S}_{1, \mathrm{k}}^{2}} \sqrt{\frac{\mathrm{n}_{1} \mathrm{n}_{2}\left(\mathrm{n}_{1}+\mathrm{n}_{2}-2\right)}{\mathrm{n}_{1}+\mathrm{n}_{2}}} \\
&-\mathrm{t}\left(\mathrm{n}_{1}+\mathrm{n}_{2}-2\right) \\
& \mathrm{S}_{\mathrm{w}, \mathrm{k}}^{2}=\sum_{\mathrm{t}}\left(\mathrm{CAR}_{\mathrm{w}, \mathrm{i}, \mathrm{k}}-\mathrm{CAR}_{\mathrm{w}, \mathrm{k}}\right)^{2} /\left(\mathrm{n}_{1}-1\right) \\
& \mathrm{S}_{1, \mathrm{k}}^{2}=\sqrt{\left(\mathrm{CAR}_{\mathrm{l}, \mathrm{i}, \mathrm{k}}-\mathrm{CAR}_{1, \mathrm{k}}\right)^{2} /\left(\mathrm{n}_{2}-1\right)}
\end{aligned}
$$

$\mathrm{CAR}_{\mathrm{w}, \mathrm{i}, \mathrm{k}}$ is cumulative average abnormal returns of the stock of $i$ of winner portfolio in the $\mathrm{k}$ month, $\mathrm{CAR}_{1, \mathrm{i}, \mathrm{k}}$ is cumulative average abnormal returns of the stock of $i$ of loser portfolio in the k month, $\mathrm{S}_{\mathrm{wk}}^{2}$. $\mathrm{S}_{\mathrm{lk}}^{2}$ is a separate variance of $\mathrm{CAR}_{\mathrm{w}, \mathrm{k}}$ and $\mathrm{CAR}_{\mathrm{l}, \mathrm{k}}$.

\section{Empirical Results}

According to the above methods and design, we get the descriptive results from Table 1.

\begin{tabular}{|c|c|c|c|c|c|}
\hline \multirow{2}{*}{ Formation period } & \multicolumn{5}{|c|}{ Test period CAR } \\
\hline & & One months & Three months & Six months & Twelve months \\
\hline \multirow{4}{*}{ Three months } & Winner portfolio $\mathrm{W}$ & -0.01091 & -0.01118 & -0.00393 & -0.00229 \\
\hline & Loser portfolio L & 0.002313 & 0.001551 & 0.002912 & 0.003151 \\
\hline & L-W & 0.013233 & 0.012731 & 0.006842 & 0.005441 \\
\hline & Value of $t$ & 1.5461 & 1.4192 & 1.2447 & 1.3853 \\
\hline \multirow{4}{*}{ Six months } & Winner portfolio $\mathrm{W}$ & -0.014 & -0.00156 & -0.00653 & -0.00546 \\
\hline & Loser portfolio $\mathrm{L}$ & 0.016834 & 0.010044 & 0.012119 & 0.004968 \\
\hline & L-W & 0.030834 & 0.011604 & 0.018649 & 0.010428 \\
\hline & Value of $t$ & 2.1109 & 1.5621 & 1.8849 & 1.2931 \\
\hline \multirow{4}{*}{ Twelve months } & Winner portfolio $\mathrm{W}$ & 0.006562 & -0.00335 & -0.01034 & -0.00404 \\
\hline & Loser portfolio L & 0.00423 & 0.009084 & 0.016559 & 0.001974 \\
\hline & L-W & -0.002332 & 0.012434 & 0.026899 & 0.006014 \\
\hline & Value of $t$ & -0.3019 & 1.2419 & 1.9973 & 1.3318 \\
\hline \multirow{4}{*}{ Twenty-four months } & Winner portfolio $\mathrm{W}$ & 0.005093 & -0.00194 & -0.01582 & 0.000971 \\
\hline & Loser portfolio $\mathrm{L}$ & 0.003396 & 0.008004 & 0.01385 & 0.002078 \\
\hline & L-W & -0.001697 & 0.009944 & 0.02967 & 0.001107 \\
\hline & Value of $t$ & -0.6261 & 1.1173 & 1.7522 & 1.4208 \\
\hline
\end{tabular}

As shown in Table 1, when the formation period was 12 months or 24 months, and test period was one month, the average cumulative abnormal return of winner portfolio got slightly higher than that of loser portfolio, which means that the performance of winner portfolio of higher abnormal returns in

Table 1.

Average cumulative excess return of the winner and loser portfolios.

Note: The level of statistical test is $5 \%$, and threshold of $t$ is 1.2856 . 
formation period is significantly better than that of the loser portfolio in the test period, and there was no over-reaction this time. But other times, the average cumulative abnormal returns of loser portfolio were higher than that of winner portfolio, when the formation and test periods were six months and one month respectively, the difference of the average cumulative abnormal monthly return between the loser and winner portfolios reached a maximum of $3.08 \%$. In the significance test, the difference between the winner and loser portfolios in abnormal return reached the level of $10 \%$ in the test period, which significantly deviates from zero. As for the degree of over-reaction, no increase of its effect was observed as time went on from Figures 1 and 2. Obviously, one who bought the ill-performed loser portfolio at an early stage and sold the well-performed winner portfolio could get significant arbitrage profit.

\section{The Test of Risk Effect}

The present study hypothesizes a "risk effect" of OSM. The hypothesis takes OSM to be a reasonable reflection of the changes in the risk, which is to be understood as a series of negative abnormal returns capable of causing the fluctuations of the value $\beta$ of stock, and their resultant fluctuations of the expected return. Financial leverage is changing along with the changes of securities prices. So the negative correlation between risk and market value is reasonable. If the risk is taken into consideration, there may not be over-reaction. Using data of the Belgian stock market, Vermaelen and Verstringe reexamined over-reaction and showed that over-reaction was a reasonable reflection of the changes in the risk. Chan (1988) found that because of the changing risk, there is weak reversion effect in the abnormal returns (Chan, 1988), But studies previous to Chan's showed high abnormal returns, In order to prove the high abnormal return on stock market at reversion effect in the long-term, the present paper uses the following model of Chan (1988) to test changing of the risk.

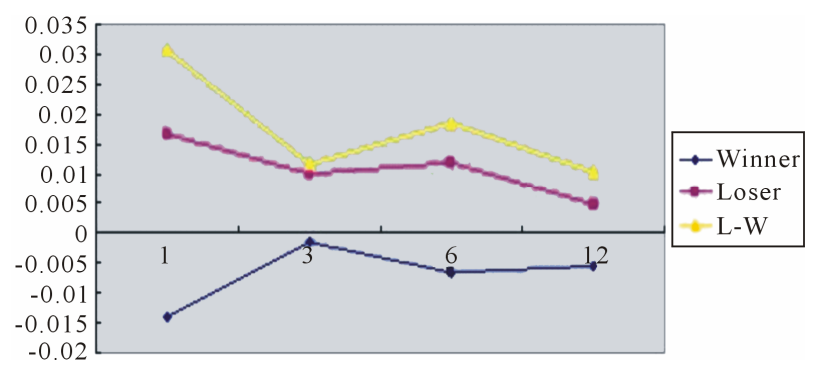

Figure 1.

CAR chart of formation period of 6 months.

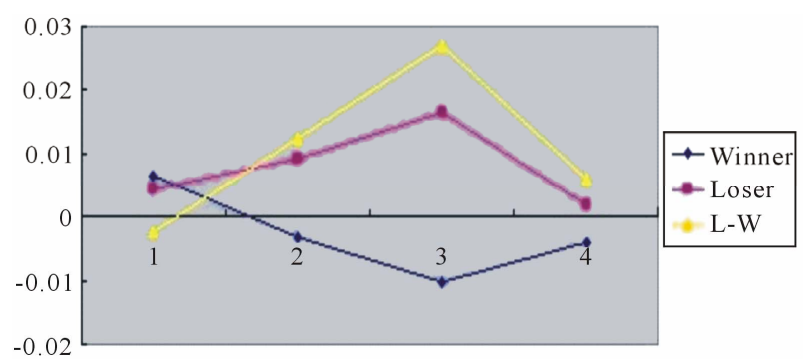

Figure 2.

CAR chart of formation period of 12 months.

$$
\begin{gathered}
\mathrm{R}_{\mathrm{a}, \mathrm{k}}=\alpha+\beta\left(\mathrm{R}_{\mathrm{m}, \mathrm{k}}-\mathrm{R}_{\mathrm{f}, \mathrm{k}}\right)+\theta_{\mathrm{k}} \\
\mathrm{R}_{\mathrm{a}, \mathrm{k}}=\mathrm{R}_{1, \mathrm{k}}-\mathrm{R}_{\mathrm{w}, \mathrm{k}}
\end{gathered}
$$

$R_{a, k}$ is the difference of the abnormal return between winner and loser portfolios in period of $\mathrm{k}$.

$\mathrm{R}_{\mathrm{f}, \mathrm{k}}$ is the risk-free interest rate in period of $\mathrm{k}$ which uses bank deposit rates from the current 3 months.

$R_{m, k}$ is the average return rate of the stock market in the same period.

$\mathrm{R}_{\mathrm{l}, \mathrm{k}}$ is the return rate of the loser portfolio in period of $\mathrm{k}$.

$\mathrm{R}_{\mathrm{w}, \mathrm{k}}$ is the return rate of the winner portfolio in period of $\mathrm{k}$.

$A$ is the abnormal return, and $\beta$ is the risk factor.

Based on the data on formation period and test periods of 3 months and 6 months separately, could obtain the following results could be obtained.

We can tell from Table 2, that, firstly $\alpha$ value at 5\% level was significant, secondly, the $\beta$ value in the formation period of six months and test period of six months was significant, and, thirdly, the others were insignificant. This indicates that the changing risk premium in reversion strategy does not adequately explain the abnormal return. This conclusion supports the finding of De Bondt and Thaler (1985). In the short term, the arbitrage portfolio they created bought stocks of the loser portfolio and sold stocks of winner portfolio, then, least square method was used in a regression analysis to examine the difference of abnormal return between loser portfolio and winner portfolio. And the conclusions showed $\beta$ value of loser portfolio in test period is 0.220 , which is larger than winner portfolio; the differences in risk therefore do not explain the arbitrage portfolio return.

\section{Conclusion}

According to the empirical analysis from January 2007 to June 2011 on stock market in Shanghai, the conclusions are as follows:

Firstly, there was OSM in China. And the overreaction was not obvious except in the cases where the formation period was twelve or twenty-four months while their corresponding test periods were both one month. In the other periods there were more obvious overreactions, as a general rule, the gradual weakening of overreaction was accompanied with the prolonging of test period. For example, the difference value of Cumulative Abnormal Return of winners and losers was 0.0308 when the formation period was six months and test period was one month, but while the test period was twelve months, this value

Table 2.

Regression results of arbitrage portfolio of stock market in Shanghai.

\begin{tabular}{cccc}
\hline \multicolumn{4}{c}{$\mathrm{R}_{\mathrm{a}, \mathrm{k}}=\alpha+\beta\left(\mathrm{R}_{\mathrm{m}, \mathrm{k}}-\mathrm{R}_{\mathrm{f}, \mathrm{k}}\right)+\theta_{\mathrm{k}}$} \\
\hline Reversion strategy & $\alpha$ & $\beta$ & $\mathrm{R}^{2}$ \\
\hline $\mathrm{X}=3, \mathrm{~J}=3$ Value of $\mathrm{t}$ & 0.021 & 0.011 & 0.0102 \\
& 3.810 & 1.179 & \\
$\mathrm{X}=3, \mathrm{~J}=$ 6 Value of $\mathrm{t}$ & 0.029 & 0.021 & 0.007 \\
& 2.995 & 0.760 & \\
$\mathrm{X}=6, \mathrm{~J}=3$ Value of $\mathrm{t}$ & 0.131 & 0.092 & 0.021 \\
& 4.952 & 1.984 & \\
$\mathrm{X}=6, \mathrm{~J}=$ 6 Value of $\mathrm{t}$ & 0.037 & 0.063 & \\
\end{tabular}


was only 0.0104 .

Secondly, to prove that there was high abnormal return on stock market at reversion effect in the long-term, the model of Chan (1988) is used in our explanation of OSM to test the changing of the risk. The results showed that the changing risk premium with reversion effect did not well explain abnormal returns.

The OSM in Shanghai can be partially explained by relevant theories of behavioral finance, such as "conservative", "characterization of inspiration thinking", "over-confidence", "biased self-attribution", and other investment own cognitive biases. However, we believed that except for these, we should take into consideration the specific institutional background and market structure of stock market in the Chinese mainland. Currently, retail is what dominates the structure of stock market in the Chinese mainland, where retail investors' information is unavailable to institutional investors, hence the information asymmetry between institutional investors and retail investors. Under these constraints, investors in the Chinese mainland often lack a philosophy of long-term investment, resulting in large fluctuations in stock prices from which many investors can make profit (Huang Jun \& Chen Ping, 2009). In the entire stock market, standardization is lacking in many places. False information, fraud in financial reports, and manipulation often occurred in listed corporations. Bankers' manipulation may cause a stock to soar in a short term or even a few years, but, when these actions are exposed to securities' and regulatory authorities' investigation, price of the stock may decline in a row again.

\section{REFERENCES}

Liu Li 刘力(1999). Xingwei jinrong lilun dui xiaolü shichang jiashuo de tiaozhan 行为金融理论对效率市场假说的挑战. Jingji kexue, 3, 63-71.

De Bondt, W. F. M., \& Thaler, R. H. (1985). Does the stock market overreact. Journal of finance, 40, 793-808.

Lehmann, B. (1990). Fads, martingales, and market efficiency. Quarterly Journal of Economics, 105, 1-28.

Zhang Renji 张人瞕, Zhu Pingfang 朱平芳, \& Wang Huaifang 王怀 芳 (1998). Shanghai zhengquan shichang guodu fanying de shizheng jianyan 上海证券市场过度反应的实证检验. Jingji kexue, 5, 58-64.

Zhu Shaoxing 朱少醒 (2000). Xingwei jinrong lilun kuangjia xia de jinrong shichang weiguan jiegou yanjiu 行为金融理论框架下的金 融市场微观结构研究. Shanghai: Shanghai jiaotong daxue.

Song Xianzhong 宋献中, \& Tang Sheng 汤胜 (2006). Zhongguo gushi "guodu fanying" yu "guimo fanying" de shizheng fenxi-Jiyu Zhongguo Shanghai A gu gupiao shichang de jianyan 中国股市 “过 度反应” 与 “规模效应” 的实证分析一一基于中国上海 $\mathrm{A}$ 股股票 市场的检验. Jinan xuebao, 3, 74-78.

Chan, K. C. (1988). On the contrarian investment strategy. Journal of business, 61, 147-164.

Huang Jun 黄俊, \& Chen Ping 陈平 (2009). Woguo gushi fanying guodu yu fanying buzu de shizheng yanjiu 我国股市反应过度与反 应不足的实证研究. Lilun yu shijian, 6, 91-94. 